\title{
Prędkość fali tętna - wartości referencyjne i zastosowanie
}

\author{
Pulse wave velocity - reference range and usage
}

\author{
Andrzej Molisz ${ }^{1}$, Małgorzata Faściszewska ${ }^{2}$, Beata Wożakowska-Kapłon ${ }^{3,}{ }^{4}$, Janusz Siebert ${ }^{1}$ \\ ${ }^{1}$ Katedra i Zakład Medycyny Rodzinnej Międzyuczelnianego Uniwersyteckiego Centrum Kardiologii \\ Gdańskiego Uniwersytetu Medycznego \\ ${ }^{2}$ Uniwersyteckie Centrum Kliniczne w Gdańsku \\ ${ }^{3}$ I Klinika Kardiologii i Elektroterapii Świętokrzyskiego Centrum Kardiologii w Kielcach \\ ${ }^{4}$ Wydział Nauk o Zdrowiu Uniwersytetu Jana Kochanowskiego w Kielcach
}

\section{Streszczenie}

Istnieje wiele markerów oceny ryzyka chorób sercowo-naczyniowych, wciąż jednak poszukuje się nowych, opisujących stan oraz ryzyko zarówno osób zdrowych, jak i obciążonych chorobami układu sercowo-naczyniowego. Do proponowanych wskaźników należy prędkość fali tętna (PWV) mierzona metodą tonometrii aplanacyjnej. Mimo, że jest to wielkość znana od dawna, dopiero w 2010 roku opublikowane zostały wyniki wieloośrodkowego projektu Reference Values for Arterial Stiffness Collaboration, w którym określono jej wartości referencyjne. Do powszechnego wykorzystania otrzymanych wartości referencyjnych niezbędne są dalsze badania wyjaśniające, czy zakres wartości prawidłowych PWV powinien być wyznaczony względem wieku, wartości średniego ciśnienia tętniczego, siatki centylowej czy ustalonych wartości granicznych. Wciąż jest niepewne, czy PWV sprawdzi się jako nowy niezależny biomarker ryzyka sercowo-naczyniowego. Słowa kluczowe: prędkość fali tętna, analiza fali tętna, tonometria aplanacyjna, wartości referencyjne, sztywność naczyń krwionośnych

(Folia Cardiologica 2015; 10, 4: 268-274)

\section{Wstęp}

Opis epidemiologiczny jest istotnym elementem charakterystyki każdej choroby. Do podstawowych markerów ryzyka chorób sercowo-naczyniowych zalicza się ciśnienie tętnicze skurczowe, ciśnienie tętnicze rozkurczowe oraz wartość wskaźnika wyliczonego według skali SCORE (Systematic COronary Risk Evaluation). Mają one określoną wartość predykcyjną i wartości referencyjne. Wciąż poszukiwane są jednak nowe biomarkery opisujące stan oraz ryzyko zarówno u osób zdrowych, jak i obciążonych chorobami układu sercowo-naczyniowego. Podejmowane są próby zróżnicowania pacjentów z podobnymi wartościami ciśnienia tętniczego względem nowych parametrów [1].
Do proponowanych wskaźników należą zmienne otrzymywane przede wszystkim metodą tonometrii aplanacyjnej, takie jak prędkość fali tętna (PWV, pulse wave velocity), wskaźnik wzmocnienia (Al, augmentation index) czy parametry tętna centralnego [2, 3]. Największą wartość predykcyjną wydaje się mieć pierwszy z wymienionych wyżej wskaźników.

\section{Metodologia}

\section{Fizjologia}

Ugruntowaną wartość epidemiologiczną ma zarówno PWV, jak i parametry wyprowadzane metodą analizy fali tętna (PWA, pulse wave analysis), w tym przede wszystkim Al [4].

Adres do korespondencji: lek. Andrzej Molisz, Katedra i Zakład Medycyny Rodzinnej, Międzyuczelniane Uniwersyteckie Centrum Kardiologii, Gdański Uniwersytet Medyczny, ul. Dębinki 2, 80-211 Gdańsk, e-mail: amol@gumed.edu.pl 
Fala tętna przemieszczająca się obwodowo odbija się od tętniczek oporowych i powraca do serca, zwiększając po drodze wartość ciśnienia tętniczego. Wartość PWV zależy od sztywności, elastyczności i podatności układu tętniczego. U osób młodych, z elastycznymi naczyniami, fala tętna przemieszcza się powoli, w związku z czym do serca powraca późno, trafiając na okres rozkurczu. Jest to sytuacja korzystna, ponieważ ciśnienie rozkurczowe zwiększa się, a ciśnienie tętna (PP, pulse pressure) się obniża, więc ciśnienie skurczowe nie jest nadmiernie podwyższane. U takich pacjentów zarówno PWV, jak i Al są niskie (AI może mieć ujemną wartość). Odwrotna sytuacja ma miejsce u osób starszych, zwłaszcza obciążonych miażdżycą czy chorobami zwiększającymi sztywność naczyń. Fala tętna przemieszcza się szybko i dociera do serca jeszcze w czasie skurczu, zwiększając wartość ciśnienia. Jest to sytuacja niekorzystna, w której ciśnienie skurczowe często przyjmuje bardzo wysokie wartości, przy niskim ciśnieniu rozkurczowym. Może to prowadzić do rozwoju, typowego dla osób w podeszłym wieku, izolowanego nadciśnienia skurczowego, przy którym ciśnienie skurczowe przekracza prawidłowe wartości, natomiast ciśnienie rozkurczowe pozostaje w zakresie normy. W tej sytuacji wysokie wartości przyjmują PWV, Al oraz PP.

\section{Technika pomiaru \\ Metody badania}

Oceny parametrów fali tętna można dokonać przy użyciu różnego rodzaju urządzeń, z których najbardziej popularnym jest tonometr aplanacyjny. To urządzenie, które rekonstruuje falę ciśnienia aortalnego na podstawie fali tętna zarejestrowanej na obwodzie. Owa metoda została określona przez amerykańską Agencję ds. Żywności i Leków (FDA, Food and Drug Administration) jako wiarygodna i porównywalna z metodami krwawymi. Inną metodą jest rejestracja tętna tętnicy szyjnej, zakładająca zgodność z tętnem aortalnym, co w wielu przypadkach stanowi istotne ograniczenie. Wysoka czułość tonometru aplanacyjnego umożliwia rejestrację krzywych, będących wiernym odwzorowaniem fali ciśnienia i uzyskanie dynamicznej krzywej, na której wyraźnie widać moment pojawiania się fali ciśnienia w miejscu pomiaru.

\section{Warunki badania}

Należy pamiętać, że na wartość PWV wpływa wiele czynników - ciśnienie tętnicze, objętość wyrzutowa i częstość rytmu serca, opór naczyniowy, odbita fala tętna, napięcie wazomotoryczne. Dlatego, aby zapewnić wiarygodność wyników, konieczne są odpowiednie warunki pomiaru zbliżone do codziennego stanu spoczynku. W konsensusie dotyczącym zastosowania tonometrycznego pomiaru PWV w codziennej praktyce przedstawiono następujące warunki prawidłowego pomiaru:
- osoba badana powinna przed pomiarem pozostawać w spoczynku przez co najmniej 10 minut w spokojnym miejscu, w temperaturze pokojowej;

- nie powinna spożywać posiłków, pić napojów zawierających kofeinę ani palić papierosów przez minimum 3 godziny przed badaniem, a także powstrzymać się od picia alkoholu przez co najmniej 10 godzin poprzedzających badanie;

- osoba badana nie może mówić ani spać podczas pomiaru;

- preferowana jest postawa leżąca;

- każde kolejne badanie powinno być wykonywane w tej samej pozycji i porze dnia, by zminimalizować zmienność wyników;

- jeśli podejrzewamy efekt białego fartucha, należy wykonać kilka pomiarów porównawczych lub powtórzyć badanie przy kolejnych wizytach;

- migotanie przedsionków, arytmia mogą utrudnić lub uniemożliwić dokonanie pomiarów [5].

\section{Wynik badania}

Na wartość wyniku badania tonometrycznego może wpływać technika pomiaru zastosowana w urządzeniu [6]. Dla aparatu SphygmoCor, który jest z reguły punktem odniesienia dla pozostałych urządzeń, osobno jest wykonywana analiza PWA oraz badanie PWV. W wyniku, oprócz wartości PWV, są prezentowane wykresy dla tętnicy szyjnej oraz udowej, obrazujące dokonane pomiary, a także odniesienie wartości PWV badanego pacjenta do populacji zdrowej oraz ogólnej populacji europejskiej w danym przedziale wartości ciśnienia skurczowego. Każdorazowo oceniana jest jakość przeprowadzonego badania (ryc. 1, 2).

\section{Wartości referencyjne}

Ograniczeniem powszechnego zastosowania PWV zmierzonego metodą tonometrii aplanacyjnej był brak jednoznacznych wartości normalnych i referencyjnych opartych na badaniach populacyjnych oraz brak standaryzacji metod pomiaru PWV. Dostępne dane dotyczyły jedynie pewnych grup pacjentów i bazowały na jednej metodzie pomiaru. Dopiero w 2010 roku opublikowane zostały wyniki wieloośrodkowego projektu Reference Values for Arterial Stiffness Collaboration, do którego włączono ponad 16500 badanych z 13 europejskich ośrodków [7]. Przedstawiono w nich wartości ustalone w oparciu o badanie osób nieleczonych z powodu nadciśnienia lub hiperlipidemii, bez jawnych chorób sercowo-naczyniowych oraz cukrzycy $(n=11$ 092). Badani zostali skategoryzowani według wieku i następnie podzieleni na podgrupy zależnie od wartości ciśnienia tętniczego. Wyodrębniono podgrupę osób z optymalnym i normalnym ciśnieniem tętniczym $(n=1455)$, bez dodatkowych czynników ryzyka sercowo-naczyniowego, w której określono wartości fizjologiczne (normalne) PWV. Wartości 


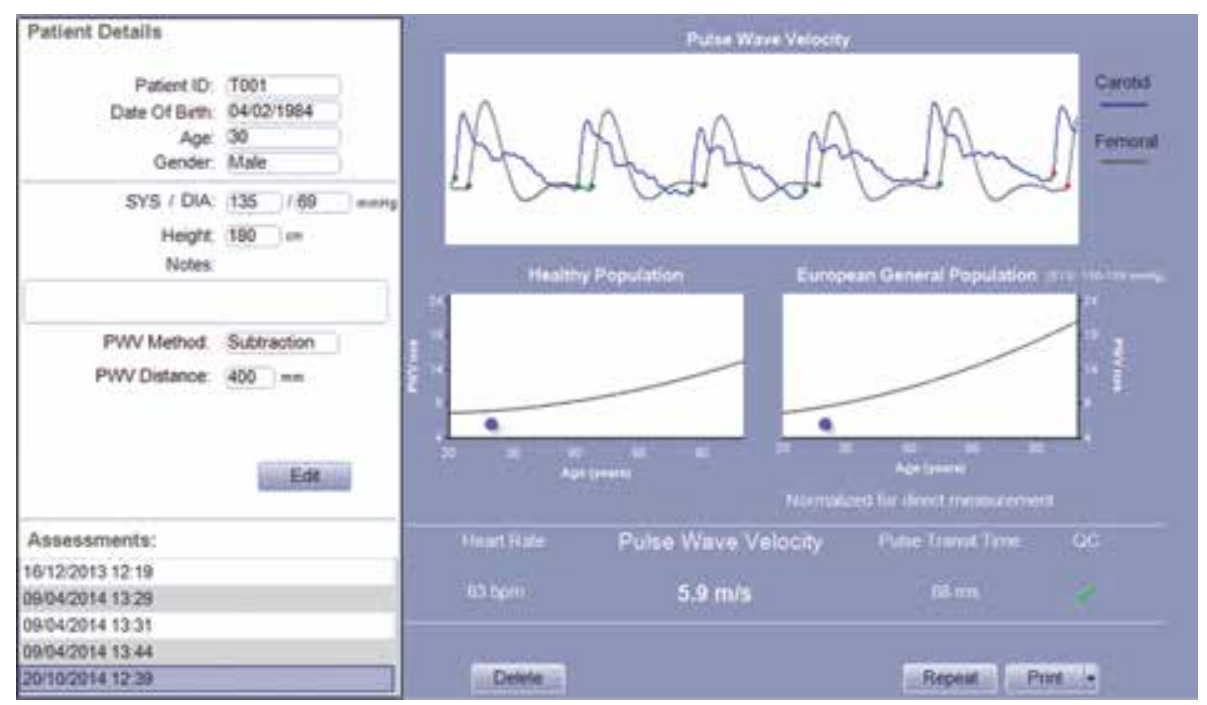

Rycina 1. Badanie prędkości fali tętna (PWV, pulse wave velocity) u 30-letniego mężczyzny; SYS (systolic blood pressure) - przedział wartości referencyjnych, w których mieści się dany pomiar; QC (quality control) - kontrola jakości; prezentowany wynik jest niższy od średnich wartości europejskich oraz średnich w zdrowej populacji

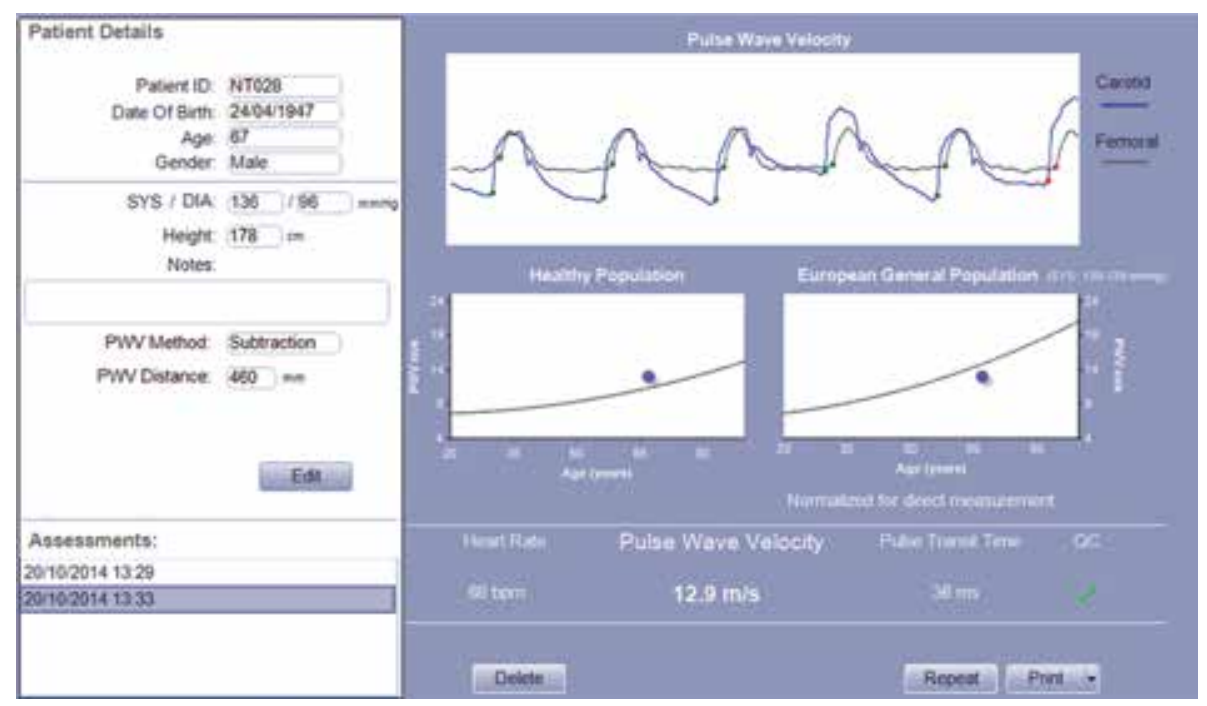

Rycina 2. Badanie prędkości fali tętna (PWV, pulse wave velocity) u 67-letniego mężczyzny; SYS (systolic blood pressure) - przedział wartości referencyjnych, w których mieści się dany pomiar; QC (quality control) - kontrola jakości; prezentowany wynik jest nieco niższy od średnich wartości europejskich, ale przekracza średnią wartość w zdrowej populacji

referencyjne wyznaczono natomiast w oparciu o badanie pozostałych osób, obciążonych jakimkolwiek tradycyjnym czynnikiem ryzyka, stanowiących populację najbardziej zbliżoną do ogólnej.

Ośrodki uczestniczące w projekcie wykorzystywały różne techniki pomiaru PWV. Udowodniono, że zastosowanie innego algorytmu obliczającego czas propagacji w odniesieniu do tej samej fali może skutkować różnicą w wartości PWV rzędu 5-15\%, natomiast różnica długości odcinka szyjno-udowego prowadzi nawet do 30\% rozbieżności w wynikach. Dlatego też, by zapewnić wiarygodność wyników i umożliwić porównanie danych ze wszystkich ośrodków, konieczne było ujednolicenie metodologii badań. Jako technikę referencyjną obliczania czasu propagacji fali (TT, $\Delta \mathrm{t}$ ) wybrano, ze względu na największą stałość i miarodajność wyników, zastosowany w aparacie SphygmoCor algorytm oparty na przecinających się stycznych (intersecting tangents). Do określenia długości ścieżki użyto skorygowanego pomiaru bezpośredniego odcinka między tętnicą szyjną wspólną a tętnicą udową. Zastosowanie pomiaru bezpośredniego odcinka szyjno-udowego ( $\times$ bezpośredni) zawyża wartość PWV w porównaniu z PWV rzeczywistym otrzymanym za 
pomocą pomiarów inwazyjnych. Użycie współczynnika korygującego 0,8 przedstawionego przez Sugawara i wsp. oraz Webera i wsp. umożliwia uzyskanie wartości PWV wiarygodnych i najbardziej zbliżonych do rzeczywistych $[5,8]$ :

\section{$\mathrm{PWV}=0,8 \times$ bezpośredni $/ \Delta \mathrm{t}[\mathrm{m} / \mathrm{s}]$}

Rozkład wartości normalnych PWV z podziałem na kategorie wiekowe przedstawiono $w$ tabeli 1.

W nieobciążonej tradycyjnymi czynnikami ryzyka populacji wartość PWV wzrasta z wiekiem od średniej wartości $6,2 \mathrm{~m} / \mathrm{s}$ u osób poniżej 30. roku życia oraz do 10,9 m/s w grupie powyżej 70. roku życia. Różnica między wartościami skrajnymi jest niewielka w najmłodszych grupach wiekowych i zwiększa się z wiekiem. Osoby z optymalnym i normalnym ciśnieniem tętniczym cechuje najniższa wartość PWV i najmniejszy wzrost PWV z wiekiem. Prawdopodobnie przyspieszenie fali tętna $z$ wiekiem byłoby

Tabela 1. Prędkość fali tętna - wartości normalne skategoryzowane względem wieku

$\begin{array}{lcc}\text { Wiek (lata) } & \text { Średnia }( \pm 2 \text { SD) } & \text { Mediana (10.-90. pc) } \\ <30 & 6,2(4,7-7,6) & 6,1(5,3-7,1) \\ 30-39 & 6,5(3,8-9,2) & 6,4(5,2-8,0) \\ 40-49 & 7,2(4,6-9,8) & 6,9(5,9-8,6) \\ 50-59 & 8,3(4,5-12,1) & 8,1(6,3-10,0) \\ 60-69 & 10,3(5,5-15,0) & 9,7(7,9-13,1) \\ \geq 70 & 10,9(5,5-16,3) & 10,6(8,0-14,6)\end{array}$

SD (standard deviation) - odchylenie standardowe; 10. pc - górna granica 10. percentyla; 90. pc - dolna granica 90 . percentyla w tej grupie jeszcze mniejsze, gdyby wyłączono z badania osoby obciążone innymi czynnikami ryzyka, takimi jak stres czy dodatni wywiad rodzinny w kierunku chorób układu sercowo-naczyniowego (CVD, cardiovascular disease). Wartości referencyjne dla każdej z badanych kategorii wiekowych i kategorii ciśnienia tętniczego osobno przedstawiono w tabeli 2.

Wiek i ciśnienie tętnicze są najważniejszymi determinantami wartości PWV. Pozostałe czynniki ryzyka takie jak dyslipidemia, palenie tytoniu czy płeć, po korekcji względem kwadratu wieku, nie wykazują niezależnego wpływu na PWV lub wpływ ten jest nieistotny. Wartość PWV wyraźnie wzrasta z wiekiem i w każdej grupie wiekowej jest dodatnio liniowo związana z ciśnieniem tętniczym. Ponadto nadciśnienie wzmacnia negatywny wpływ starzenia się na sztywność tętnic, wobec czego zależność PWV od średniego ciśnienia tętniczego (MBP, mean blood pressure) jest najsilniejsza w populacji osób w podeszłym wieku.

Nachylenie krzywych relacji wieku i PWV oraz MBP i PWV wzrasta 1,5-krotnie między osobami młodszymi lub z prawidłowym ciśnieniem tętniczym, a osobami w podeszłym wieku i obciążonymi nadciśnieniem. Autorzy pracy podkreślają fakt, że PWV w pojedynczej podgrupie, wyodrębnionej względem wieku i ciśnienia tętniczego, wykazuje większe zróżnicowanie międzyosobnicze niż między poszczególnymi podgrupami, a wzrost szybkości nie jest spowodowany jedynie przez starzenie się i nadciśnienie. Oznacza to, że pomiar PWV może stanowić nowy marker ryzyka sercowo-naczyniowego, dostarczając informacji dodatkowych, niezależnych od wieku i tradycyjnych czynników ryzyka.

Tabela 2. Wartości referencyjne prędkości fali tętna (PWV, pulse wave velocity) skategoryzowane względem wieku i wartości ciśnienia tętniczego (średnia PWV m/s \pm 2 SD)

\begin{tabular}{|c|c|c|c|c|c|}
\hline \multirow[t]{2}{*}{ Wiek (lata) } & \multicolumn{5}{|c|}{$\begin{array}{l}\text { Wartości ciśnienia tętniczego [mm Hg] } \\
\text { Średnia PWV m/s ( } \pm 2 \text { SD) }\end{array}$} \\
\hline & $<120 / 80$ & $\begin{array}{l}\geq 120 / 80 \\
i<130 / 85\end{array}$ & $\begin{array}{l}\geq 130 / 85 \\
i<140 / 90\end{array}$ & $\begin{array}{l}\geq 140 / 90 \\
i<160 / 100\end{array}$ & $\geq 160 / 100$ \\
\hline$<30$ & $6,1(4,6-7,5)$ & $6,6(4,9-8,2)$ & $6,8(5,1-8,5)$ & $7,4(4,6-10,1)$ & $7,7(4,4-11,0)$ \\
\hline $30-39$ & $6,6(4,4-8,9)$ & $6,8(4,2-9,4)$ & $7,1(4,5-9,7)$ & $7,3(4,0-10,7)$ & $8,2(3,3-13,0)$ \\
\hline $40-49$ & $7,0(4,5-9,6)$ & $7,5(5,1-10,0)$ & $7,9(5,2-10,7)$ & $8,6(5,1-12,0)$ & $9,8(3,8-15,7)$ \\
\hline $50-59$ & $7,6(4,8-10,5)$ & $8,4(5,1-11,7)$ & $8,8(4,8-12,8)$ & $9,6(4,9-14,3)$ & $10,5(4,1-16,8)$ \\
\hline $60-69$ & $9,1(5,2-12,9)$ & $9,7(5,7-13,6)$ & $10,3(5,5-15,1)$ & $11,1(6,1-16,2)$ & $12,2(5,7-18,6)$ \\
\hline \multirow[t]{2}{*}{$\geq 70$} & $10,4(5,2-15,6)$ & $11,7(6,0-17,5)$ & $11,8(5,7-17,9)$ & $12,9(6,9-18,9)$ & $14,0(7,4-20,6)$ \\
\hline & \multicolumn{5}{|c|}{ Mediana PWV m/s (10.-90. pc) } \\
\hline$<30$ & $6,0(5,2-7,0)$ & $6,4(5,7-7,5)$ & $6,7(5,8-7,9)$ & $7,2(5,7-9,3)$ & $7,6(5,9-9,9)$ \\
\hline $30-39$ & $6,5(5,4-7,9)$ & $6,7(5,3-8,2)$ & $7,0(5,5-8,8)$ & $7,2(5,5-9,3)$ & $7,6(5,8-11,2)$ \\
\hline $40-49$ & $6,8(5,8-8,5)$ & $7,4(6,2-9,0)$ & $7,7(6,5-9,5)$ & $8,1(6,8-10,8)$ & $9,2(7,1-13,2)$ \\
\hline $50-59$ & $7,5(6,2-9,2)$ & $8,1(6,7-10,4)$ & $8,4(7,0-11,3)$ & $9,2(7,2-12,5)$ & $9,7(7,4-14,9)$ \\
\hline $60-69$ & $8,7(7,0-11,4)$ & $9,3(7,6-12,2)$ & $9,8(7,9-13,2)$ & $10,7(8,4-14,1)$ & $12,0(8,5-16,5)$ \\
\hline$\geq 70$ & $10,1(7,6-13,8)$ & $11,1(8,6-15,5)$ & $11,2(8,6-15,8)$ & $12,7(9,3-16,7)$ & $13,5(10,3-18,2)$ \\
\hline
\end{tabular}

SD (standard deviation) - odchylenie standardowe; 10. pc - górna granica 10. percentyla; 90. pc - dolna granica 90. percentyla 
Do powszechnego wykorzystania otrzymanych w cytowanej pracy wartości referencyjnych niezbędne są dalsze badania wyjaśniające, czy zakres wartości prawidłowych PWV powinien być wyznaczony względem wieku, wartości MBP, siatki centylowej czy ustalonych wartości granicznych.

Autorzy analizy podkreślają, że w przypadku ciśnienia tętniczego, zdefiniowanie normy względem wieku okazało się błędem i obecnie stosuje się sztywne wartości progowe. Jednakże, w przypadku PWV, wprowadzenie ustalonych wartości granicznych jest nadal kwestią dyskusyjną. Może skutkować tym, że większość starszych i obciążonych nadciśnieniem osób będzie zakwalifikowanych do grupy wysokiego ryzyka. Ten efekt można zauważyć analizując tabelę 2 i zaproponowaną w wytycznych European Society of Cardiology/European Society of Hypertension (ESC/ ESH) 2013 wartość progową PWV 10 m/s (12 m/s dla bezpośredniego pomiaru D) [5, 9]. Z zebranych danych wynika, że około połowa osób powyżej 60. roku życia kwalifikuje się do grupy większego ryzyka ze względu na PWV przekraczającą $10 \mathrm{~m} / \mathrm{s}$. Jednocześnie należy wziąć pod uwagę fakt, że pacjent może nie przekroczyć zalecanego progu, choć w porównaniu z rówieśnikami będzie miał wyraźnie przyspieszone PWV i niewątpliwie wyższe ryzyko sercowo-naczyniowe. Mimo tych ograniczeń, opublikowany w powyższej pracy rozkład wartości referencyjnych i normalnych, umożliwia identyfikację osób obciążonych wysokim ryzykiem sercowo-naczyniowym w danej grupie wiekowej, które powinny być objęte szczególną kontrolą i intensywnym postępowaniem profilaktyczno-leczniczym.

\section{Wykorzystanie w praktyce}

\section{Prędkość fali tętna}

\section{a ocena ryzyka sercowo-naczyniowego}

ocena globalnego ryzyka sercowo-naczyniowego jest powszechnie akceptowaną i stosowaną metodą prewencji i leczenia chorób układu sercowo-naczyniowego. Opiera się na założeniu, że większość chorych na nadciśnienie tętnicze obciążona jest kilkoma czynnikami ryzyka, które wzajemnie nasilają swój negatywny wpływ. Efektem jest łączne ryzyko zdarzeń sercowo-naczyniowych przewyższające ryzyko sumaryczne wynikające z poszczególnych składowych.

W przypadku chorych obciążonych uprzednio rozpoznaną chorobą układu naczyniowego, niewydolnością serca, cukrzycą i innymi istotnymi czynnikami ryzyka, kwalifikacja do grupy dużego lub bardzo dużego globalnego ryzyka jest stosunkowo łatwa. Zdecydowanie większą trudność sprawia oszacowanie rzeczywistego ryzyka pozostałej populacji. W celu prawidłowej stratyfikacji chorych, stosuje się modele do szacowania łącznego ryzyka sercowo-naczyniowego na przykład skalę SCORE. Na tej podstawie dobierane jest odpowiednie postępowanie i leczenie [9]. Należy jednak pamiętać, że wszystkie dostępne modele oceny ryzyka mają swoje ograniczenia. Dlatego też stale poszukiwane są, niezależne od tradycyjnych, prognostyki incydentów sercowo-naczyniowych. Należą do nich wykładniki bezobjawowych powikłań narządowych - sztywność tętnic odzwierciedlona wzrostem PWV, przerost lewej komory serca, grubość kompleksu intima-media tętnicy szyjnej i mikroalbuminuria. Ich zastosowanie w codziennej praktyce, jako obrazowych biomarkerów, zwiększa precyzję identyfikacji pacjentów z wysokim prawdopodobieństwem zdarzeń sercowo-naczyniowych, w momencie, gdy zmiany narządowe są nieme klinicznie i potencjalnie odwracalne. Zaletą biomarkerów tkankowych jest ich względna stałość i powolne postępowanie, w przeciwieństwie do markerów krążących, cechujących się znacznymi fluktuacjami, które mogą wpływać na poprawność oceny ryzyka sercowo-naczyniowego pacjenta. Ponadto obrazują one całkowity, długofalowy wpływ znanych i nieznanych czynników na budowę i funkcję ścian tętnic. Ulegając niewielkim, chwilowym wahaniom, zależnym głównie od wartości ciśnienia tętniczego, PWV jest wartościowym i stosunkowo prostym w zastosowaniu wykładnikiem bezobjawowego uszkodzenia narządów docelowych [10].

Wyniki wielu badań sugerowały, że ocena PWV może być użyteczna w szacowaniu ryzyka CVD. Ben-Shlomo i wsp. [11] w opublikowanej w 2014 roku metaanalizie, obejmującej łącznie 17635 uczestników, potwierdzili, że zastosowanie oceny PWV umożliwia reklasyfikację osób z grup niskiego i umiarkowanego ryzyka oraz poprawia ocenę szacunkową 10-letniego ryzyka o 13\%. Ułatwia tym samym identyfikacje pacjentów, a także podjęcie właściwego postępowania. W modelu proporcjonalnego hazardu Coxa (In) $\log _{\mathrm{e}}$ PWV jest dodatnio liniowo związana z ryzykiem każdego z ocenianych zdarzeń - chorobą wieńcową, udarem czy chorobą układu sercowo-naczyniowego. Wartości predykcyjnej PWV nie modyfikują nadciśnienie tętnicze, palenie, płeć, cukrzyca ani choroba nerek. Jest ona silniejsza w populacji młodszej (<61. rż.), choć dla osób starszych jest nadal istotna statystycznie. W praktyce wzrost PWV o $1 \mathrm{~m} / \mathrm{s}$ skutkuje zwiększeniem ryzyka incydentów sercowo-naczyniowych o 7\% u 60-letniego niepalącego mężczyzny, bez cukrzycy, nie przyjmującego leków przeciw nadciśnieniowych, z ciśnieniem skurczowym 120 mm Hg, stężeniami cholesterolu całkowitego $5,5 \mathrm{mmol} / \mathrm{I}$ oraz lipoproteiny o wysokiej gęstości (HDL, high-density lipoprotein) $1,3 \mathrm{mmol} / \mathrm{l}$.

\section{Prędkość fali tętna jako nowy marker ryzyka} Autorzy analizy sugerują, że PWV mogłoby być wykorzystywane jako nowy biomarker ryzyka sercowo-naczyniowego. Jednakże, przed wprowadzeniem do praktyki klinicznej, każdy proponowany marker powinien spełnić kryteria przedstawione przez Amerykańskie Towarzystwo Kardiologiczne (AHA, American Heart Association): 
- musi różnić się wartością między osobami nie osiągającymi i osiągającymi klinicznie istotny punkt końcowy;

- musi mieć wartość predykcyjną potwierdzoną badaniami prospektywnymi;

- musi dostarczać dodatkowych danych niezależnie od konwencjonalnych czynników ryzyka;

- musi umożliwiać reklasyfikację pacjentów, szczególnie z grup pośredniego ryzyka, dając podstawy do zmiany postępowania leczniczego;

- jego wykorzystanie musi przynieść korzyści potwierdzone w badaniach randomizowanych;

- musi być opłacalny [12].

Pomiar PWV spełnia pierwsze cztery kryteria, co znajduje potwierdzenie w wielu badaniach, między innymi w cytowanej metaanalizie. Przedmiotem dyskusji pozostaje jednak, czy PWV może być traktowane jako niezależny cel terapeutyczny i czy jego powszechne stosowanie przyniesie istotne korzyści kliniczne. Obecnie trwają badania randomizowane, na przykład badanie SPARTE (Stratégie de Prévention Cardiovasculaire Basée sur la Rigidité Arterielle), służące ocenie, czy strategia terapeutyczna modyfikująca sztywność tętnic skuteczniej zapobiega zdarzeniom sercowo-naczyniowym niż standardowo stosowana terapia. Nie ma również jednoznacznych danych na temat kosztochłonności. Wydaje się jednak, że koszt obniży się w miarę rozpowszechniania metody. Niewątpliwą zaletą pomiaru PWV w codziennej praktyce jest także nieinwazyjna, nieniosąca ryzyka metoda badania oraz wygoda dla pacjenta i badającego.

\section{Prędkość fali tętna \\ i globalna funkcja śródbłonka}

Badanie zmian zachodzących w ścianie naczynia, a także nieinwazyjną ocenę funkcji śródbłonka, umożliwia analiza PWA, uzyskana przy użyciu tonometru aplanacyjnego. Dysfunkcja śródbłonka negatywnie wpływa na sztywność dużych naczyń oraz hemodynamikę centralną i jest niezależnym prognostykiem zdarzeń sercowo-naczyniowych i śmiertelności. Ocena globalnej funkcji śródbłonka z zastosowaniem PWA została zatwierdzona jako metoda wiary- godna i łatwiejsza w szerokim zastosowaniu w porównaniu z żylną pletyzmografią okluzyjną [13-15]. Badanie polega na analizie fali tętna po podaniu agonisty $\beta_{2}$-receptora, który jest wazodylatatorem zależnym od śródbłonka, oraz nitrogliceryny, będącej niezależnym od śródbłonka dawcą tlenku azotu (NO, nitric oxide). Udowodniono, że zarówno PWV, jak i Al wykazują istotną korelację ujemną z globalną funkcją śródbłonka oraz ze zdolnością rozkurczową tętnicy ramiennej (FDM, flow-mediated dilatation), nawet u zdrowych osób. Z zaburzoną funkcją śródbłonka jest również związany wzrost centralnego ciśnienia tętna [15].

\section{Wnioski}

Zmniejszona podatność tętnic i jej konsekwencje w postaci przyspieszenia fali tętna i wczesnego powrotu fali odbitej do serca prowadzą nie tylko do podwyższenia centralnego ciśnienia skurczowego, ale także wpływają na ograniczenie wyrzutu serca i zwiększają obciążenie jego lewej komory oraz tętnic centralnych i mózgowych. Jednocześnie powrót fali odbitej przed fazą rozkurczu komory skutkuje ograniczeniem przepływu wieńcowego. Zatem zwiększona sztywność naczyń istotnie zwiększa ryzyko niedokrwienia mięśnia sercowego, udaru mózgu i niewydolności serca. Wykorzystanie tonometrii aplanacyjnej u pacjenta umożliwia wczesne rozpoznanie zmian w układzie sercowo-naczyniowym, dotyczących zarówno tętnic obwodowych, jak i krążenia centralnego, pozwalając na dokładniejszą ocenę indywidualnego ryzyka sercowo-naczyniowego. Analizy centralnej fali tętna, ciśnienia centralnego oraz PWV informują o zaburzeniach, których nie możemy stwierdzić stosując jedynie tradycyjny pomiar ciśnienia na tętnicy ramiennej. Ta wiedza pozwala na zoptymalizowanie i indywidualizację postępowania profilaktyczno-leczniczego, szczególnie u pacjentów z subklinicznymi zmianami narządowymi.

\section{Konflikt interesów}

Autorzy nie zgłaszają konfliktu interesów.

\section{Abstract}

There are numerous risk markers for cardiovascular diseases. Still new biomarkers describing condition and risk for both healthy patients and those suffering from cardiovascular diseases CVD are searched. One of these new indices is pulse wave velocity (PWV) measured by applanation tonometry. Although introduced long time ago, only in 2010 reference values where published as a result of a multicenter project called Reference Values for Arterial Stiffness Collaboration. For widespread acceptation of these values further investigation regarding if the correct values should be determined concerning age, mean blood pressure (MBP), grid percentiles or strict border values is needed. It remains uncertain if PWV will be a new independent biomarker of cardiovascular risk.

Key words: pulse wave velocity, pulse wave analysis, applanation tonometry, reference values, vascular stiffness

(Folia Cardiologica 2015; 10, 4: 268-274) 


\section{Piśmiennictwo}

1. Stepien M., Banach M., Jankowski P., Rysz J. Clinical im flow-mediated dilatation plications of non-invasive measurement of central aortic blood pressure. Curr. Vasc. Pharmacol. 2010; 8: 747-752.

2. Siebert J., Molisz A. Centralne ciśnienie tętnicze - tonometria aplanacyjna. Forum Med. Rodz. 2010; 4: 141-140.

3. Adji A., O'Rourke M.F., Namasivayam M. Arterial stiffness, its assessment, prognostic value, and implications for treatment. Am. J. Hypertens. 2011; 24: 5-17.

4. Hamilton P.K., Lockhart C.J., Quinn C.E., McVeigh G.E. Arterial stiffness: Clinical relevance, measurement and treatment. Clin. Sci. 2007; 113: $157-170$.

5. Van Bortel L.M., Laurent S., Boutouyrie P. i wsp. Expert consensus document on the measurement of aortic stiffness in daily practice using carotid-femoral pulse wave velocity. J. Hypertens. 2012; 30: 445-448.

6. Davies J.M., Bailey M.A., Griffin K.J., Scott D.J. Pulse wave velocity and the non-invasive methods used to assess it: Complior, SphygmoCor, Arteriograph and Vicorder. Vascular 2012; 20: 342-349.

7. Mattace-Raso F.U.S, Hofman A., Verwoert G.C. i wsp. Determinants of pulse wave velocity in healthy people and in the presence of cardiovascular risk factors: 'establishing normal and reference values'. Eur. Heart J. 2010; 31: 2338-2350.

8. Chiu Y.C., Arand P.W., Shroff S.G., Feldman T., Carroll J.D. Determination of pulse-wave velocities with computerized algorithms. Am. Heart J. 1991; 121: 1460-1470.
9. Mancia G., Fagard R., Narkiewicz K. i wsp. 2013 ESH/ESC Practice Guidelines for the Management of Arterial Hypertension. Blood Press. 2014; 23: 3-16.

10. Laurent S., Briet M., Boutouyrie P. Arterial stiffness as surrogate end point needed clinical trials. Hypertension 2012; 60: 518-522.

11. Ben-Shlomo Y., Spears M., Boustred C. i wsp. Aortic pulse wave velocity improves cardiovascular event prediction an individual participant meta-analysis of prospective observational data from 17,635 subjects. J. Am. Coll. Cardiol. 2014; 63: 636-646.

12. Hlatky M.A., Greenland P., Arnett D.K. i wsp. Criteria for evaluation of novel markers of cardiovascular risk: a scientific statement from the American Heart Association. Circulation 2009; 119: 2408-2416.

13. Stoner L., Young J.M., Fryer S. Assessments of arterial stiffness and endothelial function using pulse wave analysis. Int. J. Vasc. Med. 2012; 2012: 903107.

14. Wilkinson I.B., Hall I.R., MacCallum H. i wsp. Pulse-wave analysis clinical evaluation of a noninvasive, widely applicable method for assessing endothelial function. Arterioscler. Thromb. Vasc. Biol. 2002; 22: $147-152$.

15. McEniery C.M., Wallace S., Mackenzie I.S. i wsp. Endothelial function is associated with pulse pressure, pulse wave velocity, and augmentation index in healthy humans. Hypertension 2006; 48: $602-608$ 